УДК 821.161.1-3 Куприн.09

Н.Ф. Соценко

\title{
СПЕЦИФИКА ПАРОДИЙНОЙ ПРОЗЫ А.И. КУПРИНА (НА МАТЕРИАЛЕ РАССКАЗА «ПЕРВЕНЕЦ»)
}

\author{
Н.Ф. СОЦЕНКО. СПЕЦИФІКА ПАРОДІЙНОЇ ПРОЗИ О.І. КУПРІНА (НА МАТЕРІАЛІ \\ ОПОВІДАННЯ «ПЕРВІСТОК»).
}

Стаття присвячена аналізу оповідання Купріна «Первісток». За допомогою методики інтертекстуального аналізу встановлюється другий і третій план оповідання, щяо дозволяє вважати його пародією. В результаті дослідження було встановлено, що в тексті другого плану використано безліч пародійних елементів. Це дозволяє стверджувати, що Купрін пише пародію на пародію. Він відтворює всі пародійні елементи тексту другого плану і виступає як автор і як реципієнт. У статті підтверджуються теоретичні обтрунтування пародії як прояву інтертексту. Інтертекстуальний аналіз дозволяє побачити міжтекстову конвергенцію на композиційному та стилістичному рівнях між оповіданням Купріна «Первісток» $і$ повістю Тургенєва «Перше кохання». Інтертекстуальність є основною ознакою ігрової поетики Купріна і стає засобом моделювання тексту за приниипом різомного розгалуження. Теорія ігрової поетики виявилася продуктивною для аналізу оповідання «Первісток». У статті стверджується, щяо дане оповідання слід розглядати в межах неавторського циклу про письменників, який, як і всі неавторські цикли Купріна, будується за принципом різоми. Дослідницька частина статті присвячена виявленню різних типів інтертекстуальних зв'язків між оповіданням Купріна «Первісток» і повістю Тургенєва «Перше кохання». Встановлено, шо на міжтекстовий діалог «Первістка» $i$ «Першого кохання» вказують назва, композиція, сюжет і система персонажів двох творів. Теорія алюзивного письма дозволила встановити вертикальний контекст пародії Купріна. В результаті дослідження було встановлено об'єкти пародіювання обох текстів. Крім того, виявлено, що цитати й алюзї в заголовку і в тексті пародї Купріна є основними маркерами міжтекстового діалогу. Також було встановлено, щэо пародія Купріна і пародійний текст Тургенєва відносяться до типу імпліиитної пародії.

Ключові слова: алюзія, інтертекст, ігрова поетика, пародія, циитата.

Н.Ф. СОЦЕНКО. СПЕЦИФИКА ПАРОДИЙНОЙ ПРОЗЫ А.И. КУПРИНА (НА МАТЕРИАЛЕ РАССКАЗА «ПЕРВЕНЕЦ»).

В статье анализируется рассказ Куприна «Первенеи». С помощью методики интертекстуального анализа устанавливается второй и третий план рассказа, что позволяет считать его пародией. В результате исследования было установлено, что в тексте второго плана использовано множество пародийных элементов. Это позволяет утверждать, что Куприн пишет пародию на пародию. Он воспроизводит все пародийные элементы текста второго плана и выступает как автор и как реципиент. В статье подтверждаются теоретические обоснования пародии как частного проявления интертекста. Интертекстуальный анализ позволяет увидеть межтекстовую конвергенцию на композиционном и стилистическом уровне между рассказом Куприна «Первенеи» и повестью Тургенева «Первая любовь». Интертекстуальность является основным признаком игровой поэтики у Куприна и становится способом моделирования текста по принципу ризомного разветвления. Теория игровой поэтики оказалась продуктивной для анализа рассказа «Первенеи». В статье утверждается, что данный рассказ следует рассматривать в рамках неавторского ичика о писателях, который, как и все неавторские циклы Куприна, строится по принципу ризомы. Исследовательская часть статьи посвящена выявлению различных типов интертекстуальных связей между рассказом Куприна «Первенеи» и повестью Тургенева «Первая любовь». Установлено, что на межтекстовый диалог "Первения $и$ «Первой любви» указывают название, композици, сюжет и система персонажей. Теория алюзивного письма позволила установить вертикальньй контекст пародии Куприна. В результате исследования

(C) Н.Ф. Соценко, 2019

https://doi.org/10.34142/2312-1572.2019.01.67.13 
были установлены объекты пародирования обоих текстов. Кроме того, выявлено, что цитаты и аллюзии в заглавии и в тексте пародии Куприна являются основными маркёрами межтекстового диалога. Также было установлено, что пародия Куприна и пародийный текст Тургенева относятся к типу имплицитной пародии.

Ключевые слова: аллюзия, интертекст, игровая поэтика, пародия, циитата.

\section{N.F. SOTSENKO. SPECIFICITY OF A.I. KUPRIN'S PARODY PROSE (ON THE MATERIAL} OF THE STORY “THE FIRSTBORN").

The article deals with the analysis of Kuprin's story "Firstborn". With the help of the intertextual analysis technique, the second and third story plan are established, which allows considering it as a parody. As a result of the study, it has been proved that a lot of parody elements are used in the text of the second plan. It makes it possible to suggest that Kuprin writes a parody for a parody. He reproduces all parody elements of the background text and acts as an author and a recipient. The article confirms the theoretical substantiation of parody as a private manifestation of intertext. The intertextual analysis allows seeing the intertextual convergence at the compositional and stylistic levels between Kuprin's story "Firstborn" and Turgenev's narrative "First Love". Intertextuality is the main feature of Kuprin's game poetics. It becomes a way of modelling a text according to the principle of rhizome branching. The theory of game poetics has turned out to be productive for analysing the story "Firstborn". The article argues that this story should be considered in the framework of a non-author cycle about writers that, like all other non-author Kuprin's cycle, is built on the principle of rhizome. The research part of the article is dedicated to revealing various types of intertextual connections between Kuprin's story "Firstborn" and Turgenev's narrative "First Love". It has been ascertained that the intertext dialogue of "Firstborn" and "First Love" is indicated by the title, composition, plot and system characters. The theory of allusive writing has allowed us to establish a vertical context of Kuprin's parody. The research has resulted in determining the objects for parodying of both text. Besides, it has been revealed that quatations and allusions in the title and in the text of Kuprin's parody are the main markers of the intertext dialogue. It has also been proved that Kuprin's parody and Turgenev's parody text refer to the type of implicit parody.

Key words: allusion, intertext, game poetics, parody, quotation.

Представляется, что всё творчество А.И. Куприна необходимо рассматривать с позиций игровой поэтики. Игровой текст целенаправленно моделируется его творцом в расчете на последующие поиски различных версий его истолкования (часто являющихся взаимоисключающими) [31].

В статье «Научная и переводческая деятельность А.М. Люксембурга» И.В. Волков отмечает, что «игровые тексты имеют давнюю историю», что «глубоко заблуждаются те современные исследователи, которые полагают, будто игровая специфика текста - это прерогатива постмодернистской литературы» [3]. Признавая, что отождествление понятий «игровой текст» и «постмодернистский текст» стало общим местом в отечественном и зарубежном литературоведении, автор пишет: «даже поверхностное погружение в историю литературы опровергает увязку понятий “игровой текст” и “игровая поэтика" только с постмодернизмом» [3]. Справедливость этой мысли подтверждают и тема диссертационной работы «Игровая поэтика комедий А.Н. Островского рубежа 1860-1870-х годов» [7], и темы статей («Игровая поэтика пьесы И. Ильфа, Е. Петрова, М. Вольпина “Подхалимка”» [29], «Идейно-художественные функции литературной пародии в творчестве И.С. Тургенева и классицизм XVIII-XIX вв.» [13]).

Отметим, что в данной статье мы будем использовать определение термина «игровая поэтика» и «игровой текст», данное А.М. Люксембургом: «Игровая поэтика - это ... вся система художественных средств, обеспечивающих игровую специфику текста ... и совокупность литературоведческих приёмов, необходимых для выявления и анализа данного аспекта» (Цит. по [3]).

«Под игровым понимается такой вид художественного текста, в котором автором предусмотрена необходимость ... людических (игровых) ... взаимоотношений между читателем и текстом. Это достигается за счёт особых структурных характеристик произведения ... и художественных приёмов, благодаря которым знакомство читателя с текстом ... связано с разгадкой ... загадок...» (Цит. по [3]). Ссылаясь на учение М.М. Бахтина о «чужом голосе» и «чужом сло- 
ве», сходную мысль высказывает и Г.И. Лушникова: «В современной стилистике всё чаще указывается на то, что анализ художественного текста предполагает декодирование ... ассоциативных связей между единицами ... данного текста с другими текстами» [10, с. 3]. На основании этого, считает Г.И. Лушникова, в анализ художественного текста «...необходимо включать исследование категории интертекстуальности» [10, с. 3].

Интертекстуальность И.В. Волков называет среди прочих средств и приёмов поэтики игрового текста. Отметим также, что интертекстуальность - это специфическая черта прозы А.И. Куприна [15], которая открывает возможности для новых способов прочтения и интерпретации текстов. В статье Н.В. Худолей «Механизмы актуализации интертекстуальных связей в художественном тексте» (2015) описаны типы межтекстовых связей, предложенные теоретиками интертекстуальности Ж. Женеттом, Н.А. Фатеевой, Н. Пьеге-Гро, В.П. Москвиным. Все они, так же, как и Г.И. Лушникова, к элементам интертекстуальности относят заглавие, эпиграф, цитаты, аллюзии, сюжетное варьирование, но у каждого автора классификация межтекстовых связей имеет свои отличия. Например, «к элементам интертекстуальности в составе художественного произведения Н.А. Фатеева относит все компоненты текста, отсылающие читателя к другому тексту: аллюзии, цитаты, реминисценции, пародию, заглавие текста, эпиграфы, жанровые параллели с текстом-предшественником, “точечные цитаты” в виде имён персонажей и т.д.» (Цит. по [27]). Таким образом, для понимания пародии необходимо установление интертекстуальных связей анализируемого произведения.

Ни современники Куприна, ни литературоведы советского и постсоветского периода не проявили интереса к рассказу «Первенец» (1897). Говоря об автобиографичности прозы Куприна, Кулешов упоминает об этом рассказе в связи с романом «Юнкера»: «...совершенно ... достоверна фактическая сторона ... рассказа Александрова $<\ldots>$ Куприн касался её и в своём раннем рассказе “Первенец"» [8, с. 515].

Цель данной статьи - через установление интертекстуальных связей показать наличие второго плана и выявление третьего плана в рассказе Куприна «Первенец», а также функций пародии в нём.

Рассказ «Первенец» является вторым по времени создания после рассказа «Кляча» (1896), начинающего неавторский цикл о писателях и литературе [19]. В то же время рассказ «Первенец» может начинать другой мини-цикл, состоящий из трёх произведений: XII главы романа «Юнкера» (1928-1932) и рассказа (здесь и далее определение жанра условно и нуждается в уточнении) «Типографская краска» (1929). В этих произведениях варьируется один сюжет, связанный с фактом биографии писателя Куприна, - выход в свет его первого печатного произведения. Отметим, что все неавторские циклы А.И. Куприна представляют собой рассыпанные бусы, фигуру молекулы или ризомы. Термин «ризома» заимствован из ботаники и обозначает такой корешок, каждый отрезок которого даёт жизнь новому растению. «Ризома - это множество беспорядочно переплетённых отростков или побегов, растущих во всех направлениях» [5, с. 17]. Несмотря на то, что этот термин считается одним из ключевых понятий постмодернизма, учитывая особенности формы ризомы, мы будем использовать данный термин для определения специфики циклов А.И. Куприна. Интертекстуальность становится способом моделирования текста по принципу ризомного разветвления [20]. Пародирование логически примыкает к интертекстуальности [31].

В работе М.Н. Гузь пародия рассматривается как интертекст и определяется, что степень и формы интертекстуальных связей базисного и пародийного текстов зависят от вида пародии, индивидуального стиля автора.

К общим показателям интертекстуальности автор относит соответствия заглавий базисного текста и текста пародии. Кроме этого, считает Гузь, в тексте пародии обязательно присутствует опора на содержательную структуру соответствующего базисного текста, однако формы представления сюжетной структуры пародируемого прототекста в тексте пародии весьма разнообразны. К общим типологическим чертам автор также относит заимствование пародией у базисного текста системы персонажей [6].

Г.И. Лушникова относит заглавие к основным способам реализации категории интертекстуальности. «Заглавие... - господствующий элемент произведения ... полное осмысление заголовочного комплекса возможно лишь в вертикальном контексте...» $[10$, с. 15,16$]$. «Знание вертикального контекста помогает глубже проникнуть в метасемиотику ... художественного произведения» [2]. 
Название «Первенец» является аллюзией к названию повести И.С. Тургенева «Первая любовь» (1860) и способом установления связи между текстом и претекстом или первым и вторым планом, если использовать терминологию Новикова о пародийных текстах [14]. Заглавие текста Куприна представляет собой преобразованную усечённую цитату. На лингвостилистическом уровне автор меняет грамматическую категорию рода и части речи (прилагательное женского рода «первая» трансформируется в существительное мужского рода «первенец»). Эффект языковой игры очевиден.

В словаре Ожегова объясняется, что слово «первенец» имеет два значения: прямое («первый, старший ребёнок») и переносное («то, что ... создано первым по времени»). Это слово относится к высокому стилю, то есть «придаёт речи оттенок торжественности, приподнятости, свойственный ... поэтической речи» $[15$, с. 496]. В названии А.И. Куприна первое и второе значения слова накладываются друг на друга, образуя сравнительный оборот: первое произведение, как первая любовь, как первый ребёнок. Оказавшись в одном семантическом ряду, атрибутивные словосочетания «первая любовь», «первый ребёнок», «первое произведение» становятся способом воссоздания универсального образа, символизирующего душевное состояние юноши («Мне только что минуло семнадцать лет» [9: II, 89] / «Мне было тогда шестнадцать лет» [22, с. 304]). Отметим, что в разных произведениях Куприна возраст героя меняется (семнадцать / восемнадцать), как и у Тургенева (в рукописи герою пятнадцать лет, в печатном тексте - шестнадцать) [22, с. 480].

Опираясь на теорию аллюзивной речи («Ключевой риторической фигурой аллюзивного письма следует признать ... метаболу <...> будучи точкой пересечения разнородных семантических рядов, метабола являет собой сложно организованный “гиперзнак”, смысл которого заключает в себе указание на другой, более глубокий смысл ... этот смысл может быть инспирирован в воспринимающем сознании» [23, с. 112]). При расшифровке смысла названия пародии Куприна следует обратиться к метатекстовому фрагменту из рассказа «Травка» (1912), который входит в состав двух неавторских циклов, пасхального и цикла о писателях [19], и привести рассуждения о заглавиях героя-беллетриста: «...что это за безвкусие делать заглавие рассказа из существительного и глагола? “О чём пела ласточка" “Когда мы мёртвые проснёмся”» [9, т. 5, c. 285]; « «..> дай мне простое и выразительное заглавие из одного существительного!.. - Например... “Чернильница"?! - Старая штучка! Использовал Пушкин “К моей чернильнице”» [9, т. 5, с. 285].

Данный фрагмент текста воспроизводит работу писателя и литературного критика А.И. Куприна одновременно. Обращение к названию романа немецкого писателя Фридриха Шпильгагена (1829-1911), написанного в 1872 году и переведенного на русский язык С. Майковой в 1873 году [29, с. 254], устанавливает интертекстуальную связь с этим романом и повестью Чехова «Скучная история». В своих записках герой Чехова указывает, что «...недавно ... прочёл роман под странным названием “О чём пела ласточка"» [29, с. 9]. Кроме того, название романа «О чём пела ласточка» устанавливает читательскую аллюзию с одноимённым фельетонным стихотворением А. Грина и романом И.С. Шмелёва «История любовная» (1927) - произведениями более позднего времени. Второе указанное заглавие - это цитата, которая свидетельствует о критическом прочтении Куприным современной литературы. Так называлась последняя драма Генрика Ибсена (1828-1906), написанная в 1899 году и переведенная на русский язык Ю.К. Балтрушайтисом и С.А. Поляковым в 1900 году.

Различные формы категории интертекстуальности (цитата, аллюзия, а также автоинтертекст) связывают «Первенца» и «Травку» и вовлекают в повествовательную структуру игрового текста А.И. Куприна предшествующую, современную и последующую отечественную и зарубежную литературу, реализуя принцип ризомы и выражая эстетические взгляды Купринаписателя.

Говоря о пародии, Фатеева отмечает: «Сквозь первый план текста обязательно просвечивает его второй план - текст произведения, которое излагается особым новым способом...» [25, с. 148]. «Каждый элемент нового текста изображает какую-то черту текста, который становится объектом пародии» [25, с. 149]. На межтекстовый диалог «Первенца» и «Первой любви» указывают также композиция, сюжет и система персонажей. Благодаря сходству композиционной формы угадывается второй план пародии «Первенец».

К композиционным особенностям повести Тургенева следует отнести «текст в тексте» и критически-юмористическую модальность. Из широкого массива возможных композиционных схем Тургенев выбирает рамочную композиционную форму повестей Бальзака и Пушкина 30-х 
годов XIX века («Гобсек», «Повести Белкина»). Композиция повести Тургенева представляет собой «рассказ в рассказе» со сменой рассказчиков. Первую историю, которая выглядит как короткое предисловие, сообщает безымянный повествователь. Вторую представляет Владимир Петрович, персонаж первой истории, включая в свои письменные воспоминания три романтических сюжета. Один из них сочиняет поэт Майданов, два других - о вакханках и о любви королевы - принадлежат Зинаиде. В этих сюжетах Тургенев пародийно воссоздаёт приём изображения любви в романтических произведениях («...любовь, преодолевающая все препятствия или же с трагическим финалом») [31]. О склонности Тургенева к пародированию писала и Л.Г. Тютелова («...даже в своей ранней пьесе И.С. Тургенев пародирует романтические формы») [24]. Кроме того, исследователями установлено, что сюжет Зинаиды о вакханках «...перекликается с содержанием поэмы “Сновидения" (1833) Екатерины Шаховской», которую считают прототипом тургеневской героини [22, с. 490].

Рамочная композиция является маркёром пародийного интертекста в рассказе «Первенец». Внутри рамки Куприн, как и Тургенев, помещает воспоминания героя, художественно воспроизводящие факт биографии писателя Куприна. Фабульную основу повести «Первая любовь» также представляет описание факта личной биографии Тургенева [22, с. 479-480], который трансформируется автором в многосюжетное произведение. Для сближения композиционных признаков Куприн также вставляет в своё произведение три сюжета, каждый из которого представляет собой пародию.

В первом пародийном фрагменте безымянный рассказчик, писатель в возрасте («Я уже по опыту знаю, что на литературном пути гораздо более терний, чем роз...» [9: II, 93]) воспроизводит («Я теперь не помню ясно содержание моего рассказа» [9: II, 93]) пересказ якобы сюжета своего первого печатного произведения. Имитация забывчивости - это, безусловно, игровой литературный приём, способствующий конвергенции пародийного текста с его вторым планом, так как тургеневский Владимир Петрович пишет о событиях, произошедших четверть века назад: «Я пришёл бы в большое затруднение, если бы меня заставили рассказать подробно, что происходило со мной в течение недели после моей неудачной ночной экспедиции» [22, c. 353]. Нарочитое отступление Куприна в «Первенце» от биографических фактов подтверждается фрагментами из других произведений мини-цикла. Герой-рассказчик из «Типографской краски» (повествование ведётся от первого лица) и рассказчик из «Юнкеров» (повествование ведётся от третьего лица) точно передают название и содержание первого печатного произведения писателя Куприна («...написал я рассказ “Последний дебют” из закулисной театральной жизни, которую ... никогда не видел и ничего о ней не знал» [9: VII, 374]; «...он соорудил свою ... сюиту “Последний дебют". В ней говорилось о тех ... чувствах, которых восемнадцатилетний юноша никогда не видел и не знал: театральный мир и трагическая любовь к самоубийствам» [9: VIII, 95]).

Своему вставному сюжету Куприн даёт пародийное название «Ранние слёзы», которое также коррелирует с названием повести Тургенева «Первая любовь» и финальной фразой, благодаря прилагательным «ранний / первый» [15, с. 497, 655], «утренней, весенней» и существительным «слёзы» / «грозы» [22, с. 363]. Кроме того, в названии «Ранние слёзы» отражено ироничное отношение Куприна-реципиента к стилю и содержанию второго плана. Самоирония пронизывает и всю повесть Тургенева, особенно репрезентативны XIV, XVII, XVIII главы («...я вышел ... с намерением предаться унынию, но молодость ..., свежий воздух ... взяли своё» [22, с. 339]; «...Отелло внезапно превратился в школьника» [22, с. 351]; «Отелло посвистал тоже» [22, с. 352]). Благодаря множеству интертекстуальных связей со вторым планом, пародия Куприна «Первенец» воспроизводит игровой характер литературного творчества.

В первой вставной мини-пародии «Ранние слёзы» откровенно пародируется универсальный литературный сюжет [24, с. 153; 28]: «...Вольдемар влюбился ... в Людмилу, Людмила изменила ... коварным образом Вольдемару ради кавалерийского офицера» [9: II, 89]. Можно предположить, что Куприну было известно письмо Тургеневу Луи Виардо по поводу «Первой любви»: «Снова адюльтер, всегда процветающий и прославляемый адюльтер!» [22, с. 487].

Сюжет вставной пародии Куприна «Ранние слёзы» также соотносится и с сюжетом романтической поэмы Майданова «Убийца» («Иль, может быть, соперник тайный / Тебя нежданно покорил») [22, с. 330], а та, в свою очередь, вызывает зеркально умноженный ряд аллюзий к романтическим поэмам Пушкина «Руслан и Людмила» (1820), «Цыганы» (1824), роману Стендаля «Красное и чёрное» (1830). Свою поэму «Майданов ... намеревался издать в чёрной обёртке с заглавными буквами кровавого цвета» [22, с. 321]. Кроме того, он представляет собой 
сюжет «Первой любви» наизнанку, так как Зинаида предпочла штатского Петра Васильевича гусару Беловзорову (здесь у Тургенева классицистический приём говорящих фамилий), который «...на Кавказ уехал» и «без вести пропал» [22, с. 357].

Имена героев пародийного сюжета Куприна Вольдемар и Людмила становятся интертекстуальными кодами (Руслан - Людмила, Владимир Ленский - Ольга, Владимир Смельский - Зинаида, Зинаида - Вольдемар) и воспринимаются как аллюзия к пушкинским и тургеневским героям, а также героям пародии Достоевского, включённой в роман «Бедные люди» (1845) [14]. Синтез и трансформация как приёмы игровой стратегии искажают внутренний мир образов героинь Пушкина, превращая верную Людмилу (поэма «Руслан и Людмила») в ветреную Ольгу (роман «Евгений Онегин»).

Хронотоп первой вставной мини-пародии Куприна («...было прекрасное майское утро» [9, II, 89] / «Погода стояла чудесная; мы переехали из города девятого мая...» [22, с. 304]) также соотносится с повестью Тургенева.

Вторая вставная мини-пародия Куприна отражает одну из сюжетных линий второго плана, связанную с литературным процессом и сменой литературных направлений («Поэт Венков ... обладал ... способностью повсюду втискивать гражданскую идею. < .. > Вид водопада напоминает ему пленённую мысль, разбившую насильственные оковы» [9: II, 89] / «...опять заспорите о классицизме и романтизме» [22, с. 334]), также позволяет установить конвергенцию между пародией Куприна и повестью Тургенева.

Одной из сюжетных линий в повести Тургенева является изображение смены литературных направлений. И хотя повесть написана во времена расцвета критического реализма, Тургенев жонглирует в ней романтическими приёмами, уже пародийно используя романтическую символику сада, развалин, фонтана, ночные, вечерние, утренние пейзажи, романтическое двоемирие и романтические приёмы создания героя и антигероя. Кроме того, повесть насыщена цитатами и аллюзиями романтических текстов (Шиллера «Разбойники», Пушкина «Цыганы», Стендаля «Красное и чёрное», Хомякова «Ермак»), упоминаются имена Гюго и Байрона как выдающихся представителей романтизма [22].

В тексте повести в различных функциях используются также цитата романса Вяземского «Я жду тебя, когда зефир игривый...» [22, с. 339], аллюзия, навеянная эпизодом трагедии Шекспира «Гамлет» и книга Плутарха «Жизнеописания» [22, с. 490]).

Вторым планом в повести Тургенева является пародия на подражателей романтического направления и само направление уже как факт литературной истории, а в рассказе Куприна это пародия на пародию. Пародия Куприна представляется «изысканной шутливой игрой» (понимание Набокова), которая «...позволяет говорить о пушкинском “Памятнике" как о пародии на державинский» (Цит. по [21, с. 331]).

В статье Т.В. Мельниковой отмечается, что «Тургенев расценивал классицизм как важный этап в литературном и - шире - культурном развитии человечества. И известные пародийно-полемические выпады Тургенева направлены не столько против классицизма как такового, сколько либо против его эпигонов, либо против издержек классицистического стиля» [13, c. 70].

В работе Д.В. Философова указывается, что «возродился романтизм и в современной европейской литературе, под именем символизма» [26], поэтому для Куприна данная проблема была так же актуальна, как и для Тургенева и его героев. Куприн пародийно воссоздаёт не только фрагмент претекста, не только литературную полемику между представителями «чистого искусства» и гражданской лирики, но слово-цитата «водопад» устанавливает аллюзивную связь между одой Г.Р. Державина «Водопад» (1791-1794) и стихотворением Ф.И. Тютчева «Фонтан» (1836), подчёркивая непрерывность литературной традиции или интертекстуальные связи. О глубокой связи Державина и Тютчева писал Л.В. Пумпянский («чисто державинские стихи Тютчева», «...усвоил, вместе с прочим наследием Державина, и Тютчев» $[16$, с. 47,56$])$. А современная исследовательница С.В. Галян высказывает сходную мысль и расширяет границы поэтических связей с поэзией Державина («Особое место в ряду поэтов, оказавших влияние на формирование авторского сознания Тютчева, занимает Г.Р. Державин, который был ключевой фигурой в русской литературе рубежа веков, ... его творчество стало стимулом для формирования индивидуальных авторских систем многих поэтов XIX века. Имеются специальные исследования, посвященные державинской традиции в творчестве А.С. Пушкина, Н.М. Языкова, поэтов Серебряного века и т.д.») [4]. 
В третьем пародийном фрагменте Куприн воссоздаёт образ поэта Венкова (приём говорящих фамилий вызывает аллюзию к лавровому венку, который венчает головы древних поэтов, например, известный портрет Петрарки). Неточная цитата в воссоздании образа поэта Венкова («слепые / подслеповатые глаза») позволяет соотнести два текста и увидеть различия между первым и вторым планом. По сравнению с характеристикой поэта Майданова, портретная характеристика поэта Венкова расширяется, иронический тон усиливается благодаря использованию градации и гиперболы, уменьшительно-ласкательные суффиксы придают уничижительную коннотацию («яйщевидное лицо, всё изрытое оспой ... жиденькая, ... трясущаяся бородёнка ... длинный нос, ... конический лоб, по обе стороны которого падали на плечи прямые редкие волосы» [9: II, 89], «кривые ноги», «страшные гримасы» [9: II, 90]). Усиливая пародийные ноты Тургенева, Куприн отражает девальвацию романтического образа поэта в литературе, и пушкинский образ Ленского предстаёт в гротескном изображении.

В отличие от Куприна, пародийный сниженный портрет и характер «поэта» Майданова Тургенев изображает мягкими ироничными красками («высокий молодой человек с худощавым лицом, маленькими слепыми глазами и чрезвычайно длинными чёрными волосами <... он ненужно восторгался и ... внезапно падал духом>» [22, с. 319, 362]), однако слова-цитаты соотносятся с деталями портрета и характера Ленского («Привёз... Дух пылкий ... Всегда восторженную речь / И кудри чёрные до плеч») [17, с. 30].

В повести Тургенева поэт Майданов олицетворяет всех подражателей и эпигонов романтизма («...рифмы чередовались пусто $u$ громко» $[22$, с. 330]), поэтому Зинаида «...заставляла его читать Пушкина, чтобы ... очистить воздух» [22, с. 327]. Рефлексия Зинаиды о поэзии («Вот чем поэзия хороша: она говорит нам то, чего нет и что ... лучше того, что есть...» [22, с. 330]) выполняет двойную функцию. В ней критически соотносится высокая романтическая поэзия Пушкина с произведениями эпигонов и отражается приём романтического мифотворчества («сказка есть ... канон поэзии. Всё поэтическое должно быть сказочным») [31].

Другим маркёром интертекста как вида пародии между рассказом А.И. Куприна «Первенец» и повестью И.С. Тургенева «Первая любовь» является слово-цитата в указании топоса («Это случилось в Москве» [9: II, 89] / «Я жил в Москве...» [22, с. 304] (курсив мой. - Н. С.)), а также использование лексики иного стиля («С той поры прошло ... очень много лет» [9: II, 89] / «И теперь, когда на жизнь мою начинают набегать вечерние тени...» [22, с. 363]).

Обыгрывая приём высокий-низкий слог, Куприн пародирует стиль Тургенева, изображающего возбуждённое состояние юноши, вызванное первой влюблённостью и первым поцелуем, воспроизводя аналогичное состояние, но произведенное первым печатным произведением («Сердце замерло у меня в груди от какого-то сладкого предчувствия» [9: II, 91] / «Сердце во мне так и прыгало; ... я чувствовал небывалое волнение» [22, с. 308]). Текстовые переклички очевидны благодаря словам-цитатам, и они продолжаются («Припадок обуявшей меня радости ... я ... сумел ... выразить ... безумными скачками через пять ступенек сразу. ... я продолжал бесноваться, прыгая через кровати и табуретки» / «... чувство блаженства ... разрешилось восторженными прыжками и восклицаниями» [19, с. 337]). Там, где Тургенев прибегает к высокой лексике, Куприн использует слова сниженной коннотации, и наоборот. Слова-цитаты «прыжками, скачками, прыгая» и др., а также общий смысл фрагментов и ностальгический тон («Впоследствии нередко были в моей жизни моменты очень большого счастия. Но ... не испытывал я такого сильного наплыва восторга...» [9, II, 91] / «чувство блаженства ... уже не повторилось в моей жизни» [22, с. 337]) устанавливают межтекстовую связь, а слова сниженной коннотации «припадок радости» и «бесноваться» являются средством иронической стилизации претекста.

Описание чувства («Счастье пришло...» $[9$, II, 90] / «...страсть началась...» [22, с. 330]) неразделённой радости и неразделённой юношеской любви представляет содержание обоих текстов. В пародии Куприна редуцированы многие сюжетные линии претекста Тургенева, например, отношения отца и сына, любовные треугольники и четырёхугольники, кроме одной: ретроспективное воссоздание периода психологического взросления молодого человека и сожаление о его краткости.

Объём произведения - это ещё одна особенность рассказа «Первенец», которая позволяет считать его пародией. В исследовании о пародийных текстах Г.И. Лушникова указывает: «Конвергенция приёмов пародии предполагает её краткость. Как правило, в пародии, состоящей из 2-3 страниц, раскрываются характерные черты прототекста, который может обладать достаточно большим объёмом» [12]. 
Третий план пародии «Первенец» обнаруживается только в рамках цикла о писателях. В данном неавторском цикле Куприн вступает в полемику с представителями романтической и символистской литературы, создавшими образ поэта-избранника, изгнанника, мечтателя, неподкупного творца, который всегда находится в единоборстве с враждебным миром. Мотив отверженности поэта обществом Куприн воссоздаёт комически (за своё первое напечатанное произведение юнкер оказался в карцере), используя литературные штампы публицистического стиля: «...я уже знал ..., что двигатели просвещения всегда терпели и будут терпеть несправедливые нападки невежественной толпы» [9: II, 93]. Также травестийно представлен в пародии и мотив бессребреничества поэта: «Я . . , получая номер со своим произведением, ... спокойно считаю количество строк» [9: II, 93].

Если рассматривать текст «Первенца» как близнечный текст рассказа «Кляча», то обнаруживается контрастное и пародийное изображение мотива романтической и символистской литературы о миссии поэта-демиурга. Таким образом, Куприн использует повесть Тургенева в качестве текста-посредника для пародирования совсем другого объекта.

Специфика пародии Куприна близка к тому, как понимал её Набоков: «...не “крушение кумиров”, ... но их творческое обыгрывание» (Цит. по [21, с. 332]). Используя в качестве макета повесть Тургенева, Куприн показывает способность к обновлению, трансформации и модификации давно известной композиционной формы. Пародия в данном случае выступает как форма диалога с традицией. Подобно Тургеневу [13, с. 71], Куприн обращается к жанру пародии, который позволяет ему реализовать своё мастерство, выразить эстетические принципы и наиболее отчётливо проявить черты новаторства.

Таким образом, опираясь на типологию пародии, данную Лушниковой, текст Куприна «Первенец» и претекст Тургенева «Первая любовь» относятся к имплицитной пародии, так как в имплицитной, или амбивалентной пародии «...жанр не обозначен, намерения автора не могут быть декодированы однозначно. Для отнесения такого типа произведения к пародийному жанру необходимы ... исследования критиков, интерпретаторов, читателей» [12].

\section{ЛИТЕРАТУРА}

1. Вахрушева А.Н. Романтическая концепция личности в трагедии А.С. Хомякова «Ермак» // Вестник Удмуртского ун-та, Серия история и филология, 2010. URL: https://cyberleninka.ru/article/v/romanticheskaya-kontseptsiya-lichnosti-v-tragedii-a-s-homyakovaermak (дата обращения: 15.09.2018).

2. Вербицкая М.В. Теория вторичных текстов: автореф. дисс. ... доктора филологических наук: 10.02.04. Москва, 2000. URL: http://cheloveknauka.com/teoriya-vtorichnyhtekstov\#ixzz4uHPmczv4 (дата обращения: 15.09.2018).

3. Волков И.В. Научная и переводческая деятельность А.М. Люксембурга. URL: http://timili.sfedu.ru/history/luxemburg (дата обращения: 15.09.2018).

4. Галян С.В. Державинская традиция в лирике Ф.И. Тютчева: автореф. дисс. ... канд. филологических наук: 10.01.01. Екатеринбург, 2014. 23 c. URL: http://elar.urfu.ru/bitstream/10995/24009/1/urgu1348s.pdf (дата обращения: 18.09.2018).

5. Гречко П.К. Концептуальные модели истории. Ризома как метапаттерн истории. URL: www.pseudology.org/History/Grechko_Koncept_Modeli2a.pdf (дата обращения: 15.09.2018).

6. Гузь М.Н. Интертекстуальные связи базисного текста и текста пародии: на материале нем. прозаич. пародии: автореф. дисс. ... канд. филол. наук: спец. 10.02.04. СПб, 1997. 195 с. URL: http://www.dissercat.com/content/intertekstualnye-svyazi-bazisnogo-teksta-i-teksta-parodii-namateriale-nem-prozaich-parodii\#ixzz5MMlW75mh_(дата обращения: 15.09.2018).

7. Коломлина Н.А. Игровая поэтика комедий А.Н. Островского рубежа 1860-1870-х годов: автореф. дисс. ... канд. филологических наук: 10.01.01. Тамбов, 2007. 26 c. URL: https://search.rsl.ru/ru/record/01003063818_(дата обращения: 15.09.2018).

8. Кулешов Ф.И. Творческий путь А.И. Куприна. Минск, 1963. 535 с.

9. Куприн А.И. Собрание сочинений: в 9 т.; [прим. И.П. Питляр [и др.]; вступ. ст. К. Чуковского]. М.: Правда, 1964.

Т. 2: Произведения 1896-1900. 493 [2] с.

Т. 5: Произведения 1908-1913. 417 [2] с.

Т. 7: Произведения 1917-1929. 418 [1] с.

Т. 8: Произведения 1930-1934. 437 [2] с. 
10. Лушникова Г.И. Интертекстуальность художественного произведения. Кемерово, КемГУ. 1995. 82 с.

11. Лушникова Г.И. Ироническая картина мира в литературной пародии. С. 101-107. URL: https://cyberleninka.ru/article/v/ironicheskaya-kartina-mira-v-literaturnoy-parodii (дата обращения: 15.09.2018).

12. Лушникова Г.И. Когнитивные и лингвостилистические особенности литературной пародии: автореф. дисс. ... доктора филологических наук. Кемерово, 2010. 250 c. URL: http://www.dissercat.com/content/kognitivnye-i-lingvostilisticheskie-osobennosti-literaturnoi-parodii (дата обращения: 15.09.2018).

13. Мельникова Т.В. Идейно-художественные функции литературной пародии в творчестве И.С. Тургенева и классицизм XVIII-XIX вв. // Науковий вісник Міжнародного гуманітарного університету. Серія «Філологія»: зб. наук. пр. Одеса, 2014. Вип. 8. Т. 2. С. 69-71.

14. Новиков В.И. Литературная пародия: учебно-методическое пособие по курсу «Теория литературы». М.: МГУ им. М.В. Ломоносова, 2009. 39 c. URL: www.novikov.poetpremium.ru/parody/212/ (дата обращения: 15.09.2017).

15. Ожегов С.И. Словарь русского языка: 70000 слов [под ред. Н.Ю. Шведовой]. 23-е изд., испр. М.: Рус. яз., 1991. 917 с.

16. Пумпянский Л.В. Поэзия Ф.И. Тютчева // Урания. Тютчевский альманах. 1803-1928. Л.: Прибой, 1928. С. 9-57. URL: http://www.ruthenia.ru/tiutcheviana/publications/pumpjansk.html (дата обращения: 15.09.2018). $314[2] \mathrm{c}$.

17. Пушкин А.С. Евгений Онегин: роман в стихах; Драмы. Харьков: Фолио, 1999.

18. Соценко Н.Ф. Интертекстуальность прозы А.И. Куприна 1890-1900-х годов: дис. ... канд. филол. наук: спец. 10.01.02. Харьков, 2008. 210 с.

19. Соценко Н.Ф. Циклизация прозы А.И. Куприна: читательский цикл // Русская филология. Вестник Харьковского национального педагогического университета имени Г.С. Сковороды. Харьков, 2017. № 2 (61). С. 47-53.

20. Стрельникова Л.Ю. Интертекстуальность как инструмент моделирования метатекста в творчестве В. Набокова // Проблемы филологии и искусствознания. 2018. № 1. С. 224-235. URL: https://www.researchgate.net/publication/324116049_Intertekstualnost_kak_instrument_modeli rovania_metateksta_v_tvorcestve_V_Nabokova (дата обращения: 15.09.2018).

21. Сысоева О.А. Литературная пародия: проблема жанра // Вестник Нижегородского ун-та им. Н.И. Лобачевского. 2013. № 5 (1), С. 330-335. URL: https://cyberleninka.ru/article/v/literaturnaya-parodiya-problema-zhanra (дата обращения: 20.09.2018).

22. Тургенев И.С. Полное собрание сочинений и писем: в 30 т. Сочинения: в 12 т. Т. 6 : Дворянское гнездо. Накануне. Первая любовь. М.: Наука, 1981. С. 301-365; 478-492.

23. Тюпа В.И. Дискурсные формации: очерки по компаративной риторике: монография. 2-е изд., испр. и допол. М.: Издательство Юрайт, 2018. 274 с. (Серия Актуальные монографии) URL: https://books.google.com.ua/books?isbn=5041046565 (дата обращения: 21.09.2018).

24. Тютелова Л.Г. Чехов и Тургенев: проблема драматического пространства // Творчество А.П. Чехова: текст, контекст, интертекст. 150 лет со дня рождения писателя: сб. материалов Международной научной конференции. Ростов-на-Дону, 1-3 октября 2010 года. С. 313-321. URL: http://www.ssc-ras.ru/files/files/Chekhov\%20sbornik\%202011.pdf (дата обращения: 15.09.2018).

25. Фатеева Н.А. Интертекст в мире текстов: Контрапункт интертекстуальности. Изд. 2 е, испр. М.: КомКнига, 2006. 280 с.

26. Философов Д.В. Немецкий романтизм и русская литература // Речь. 1914, 6 (19) января. № 5. C. 3. URL: http://dugward.ru/library/filosofov/filosofov_nemeckiy_romantizm.html (дата обращения: 15.09.2018).

27. Худолей Н.В. «Механизмы актуализации интертекстуальных связей в художественном тексте» // Исторические, философские, политические и юридические науки, культурология и искусствоведение. Вопросы теории и практики. Тамбов: Грамота. 2015. № 11 (61): в 3-х ч. Ч. II. C. 199-202. URL: www.gramota.net/materials/3/2015/11-2/ (дата обращения: 15.09.2018).

28. Хейзинга Й. Ноmo ludens. В тени завтрашнего дня; [пер. с нидерл. и прим. В.В. Ошиса; общ. ред. и послесл. Г.М. Тавризяна]. М.: Прогресс, 1992. 458 [6] с.

29. Чехов А.П. Повести. Пьесы. М.: Правда, 1987. 460 [4] с. 
30. Шеленок М.А. Игровая поэтика пьесы И. Ильфа, Е. Петрова, М. Вольпина «Подхалимка» // Известия саратовского университета. Нов. сер. Сер. Филология. Журналистика. 2015, T. 15. Вып. 3. URL: https://cyberleninka.ru/article/v/igrovaya-poetika-piesy-i-ilfa-e-petrova-mvolpina-podhalimka (дата обращения: 15.09.2018).

31. Щербаков А.Д., Дубинина И.А. Образные художественные средства языка романов Фредерика Бегбедера «99 франков» и «Любовь живёт три года» (выпускная квалификационная работа). Краснодар, «Кубанский гос. ун-т», 2015. URL: http://www.allbest.ru/.

32. Янушкевич А.С. Путешествие в страну романтизма: новые подходы к изучению русского романтизма первой трети XIX века // Программы. Проекты. Гипотезы. URL: https://cyberleninka.ru/article/v/puteshestvie-v-stranu-romantizma-novye-podhody-k-izucheniyurusskogo-romantizma-pervoy-treti-xix-veka (дата обращения: 15.09.2018).

(Статья поступила в редакциию 19 декабря 2018 г.) 